• e ISSN-0976-6855 | Visit us : www.researchjournal.co.in

\title{
Effect of pesticidal schedule to control the shoot and fruit borer Leucinodes orbonalis in brinjal
}

\author{
D. PANDA*, S. SRICHANDAN AND K.K. BEHERA
}

Krishi Vigyan Kendra (O.U.A.T.), Larkipalli, BOLANGIR (ODISHA) INDIA

\section{ARITCLE INFO \\ Received : 05.08 .2015 \\ Revised : 01.09 .2015 \\ Accepted : 17.09 .2015}

\section{KEY WORDS :}

Borer, Brinjal, B: C, Days after transplanting, Economics

*Corresponding author:

Email: panda_debashis@yahoo.co.in

\begin{abstract}
To study the performance of various pesticidal schedules to evolve a suitable management strategy against brinjal shoot and fruit borer, the field experiment was carried out at The Central Research Station, OUAT, Bhubaneswar from January to June 2010. The findings of investigation revealed that the brinjal shoot and fruit borer caused highest fruit damage $(80.22 \%)$ at 120 days after transplanting under unprotected condition. Under protected condition, the mean fruit infestation due to shoot and fruit borer varied from 46.44 to 53.15 per cent. Among all the treatment schedule, application of cartap hydrochloride, monocrotophos, carbaryl, azadirachtin, Bt formulation and triazophos at 30, 45, 60, 75, 90 and 105 days after transplanting at 15 days interval reduced the fruit infestation successfully and registered highest fruit yield and highest monetary value (Rs. 36,070/ha).
\end{abstract}

How to view point the article : Panda, D., Srichandan, S. and Behera, K.K. (2015). Effect of pesticidal schedule to control the shoot and fruit borer Leucinodes orbonalis in brinjal. Internat. J. Plant Protec., 8(2) : 347-351. 